\title{
Feasibility of food processing as an enterprise for rural women
}

\author{
PAYAL BATRA, SHASHI KANTA VERMA AND KANTA SABHARWAL
}

Received: 27.08.2013; Revised: 30.09.2014; Accepted: 13.10.2014

See end of the paper for authors' affiliations

KANTA SABHARWAL

Department of Home Science

Extension Education and

Communication Management,

C.C.S. Haryana Agricultural

University, HISAR (HARYANA)

INDIA
ABSTRACT : It was found that the sample in Siswal village food processing was perceived very easy to understand and use, most profitable, somewhat compatible, somewhat observable and most triable. In Dhani Premnagar village, food processing was perceived very easy to understand and use, most profitable, somewhat compatible, somewhat observable and most trialable. Maximum number of respondents in pooled sample perceived the food processing technology as simplicity (mean score $4.50,1^{\text {st }}$ rank), relative advantageous (mean score $4.32,2^{\text {nd }}$ rank), triability (mean score $3.783^{\text {rd }}$ rank) observability (mean score $3.00,4^{\text {th }}$ rank) and cultural compatibility (mean score $2.96,5^{\text {th }}$ rank). Thus, it can be concluded that most of the respondents considered food processing as simplicity, relative advantageous, triable, observable and cultural compatible.

KEY WORDS: Food processing, Feasibility, Enterprise, Rural Woman

- HOW TO CITE THIS PAPER : Batra, Payal, Verma, Shashi Kanta and Sabharwal, Kanta (2014). Feasibility of food processing as an enterprise for rural women. Asian J. Home Sci., 9 (2) : 452-455. 